\title{
PENERAPAN PENDEKATAN SUPERVISI KOLABORATIF UNTUK MENINGKATKAN KOMPETENSI PROFESIONAL GURU DI SD NEGERI 2 PLANDI WONOSARI KABUPATEN MALANG
}

\author{
Mistiani \\ Kepala SD Negeri 2 Plandi Kec. Wonosari Kab. Malang \\ mistiani.ks.sdn2plandi@gmail.com
}

\begin{abstract}
The results of empirical studies conducted by the researchers on teachers at Plandi Wonosari State Elementary School 2 Malang showed that teacher professional competence was still low, especially in teacher competencies in developing learning materials that were taught creatively.

Considering these conditions, one of the efforts that can be carried out by researchers to overcome the problem of the low professional competence of teachers in carrying out their professional duties, then applied the action in the form of a supervision approach that has never been done before, namely the collaborative supervision approach.

Based on the results of the study, it can be seen that there is an increase in teacher professional competence from pre-cycle to Cycle I of 18.18 points. The average professional competence of teachers in the pre-cycle is 52.27 with less criteria and in Cycle I is 70.45 with sufficient criteria. Teacher professional competence also experienced an increase from Cycle I to Cycle II by 18.19 points. The average professional competence of teachers in Cycle II was 88.64 with good criteria
\end{abstract}

Keyword: Approach, Collaborative Supervision, Enhancing Professional Competence

\section{PENDAHULUAN}

Guru merupakan ujung tombak keberhasilan pendidikan. Profesionalisme seorang guru terlihat dari kompetensinya sebagai seorang guru yang terdiri dari kompetensi pedagogik, profesional, keperibadian dan sosial. Salah satu dimensi kompetensi guru sesuai dengan Peraturan Menteri Pendidikan Nasional Republik Indonesia Nomor 16 Tahun 2007 tentang Standar Kualifikasi Akademik dan Kompetensi Guru adalah kompetensi profesional. Dengan Permendiknas tersebut berarti seorang guru harus kompeten dalam melakukan kinerja profesionalnya. Kompetensi profesional guru menurut Permendiknas Nomor 16 Tahun 2007 terdiri dari kemampuan guru dalam: (1) menguasai materi, struktur, konsep, dan pola pikir keilmuan yang mendukung mata pelajaran yang diampu; (2) menguasai standar kompetensi dan kompetensi dasar mata pelajaran/ bidang pengembangan yang diampu; (3) mengembangkan materi pembelajaran yang diampu secara kreatif; (4) mengembangkan keprofesionalan secara berkelanjutan dengan melakukan tindakan reflektif; dan (5) memanfaatkan teknologi informasi dan komunikasi 
untuk berkomunikasi

dan mengembangkan diri.

Efektivitas pelaksanaaan kinerja profesional guru sangat bergantung pada kompetensi kepala sekolah dalam melaksanakan tugasnya diantaranya dalam melakukan supervisi akademik. Untuk melaksanakan supervisi akademik, kepala sekolah sebagai supervisor dan penanggungjawab kegiatan di sekolah harus mampu menyusun program, melaksanakan, dan melakukan tindak lanjut supervisi akademik di sekolah yang dipimpinnya. Pelaksanaan supervisi akademik yang baik oleh kepala sekolah akan menghasilkan kompetensi guru dalam memfasilitasi pembelajaran yang baik pula. Selanjutnya, pembelajaran yang dilaksanakan dengan baik akan berdampak pada peningkatan prestasi siswa. Dengan demikian, keberhasilan siswa dalam pembelajaran sangat bergantung pada kemampuan guru dalam memfasilitasi pembelajaran dan kompetensi kepala sekolah dalam melaksanakan supervisi akademik.

Kompetensi supervisi akademik kepala sekolah terdiri dari tiga aspek yaitu kompetensi dalam menyusun program, melaksanakan, mengevaluasi dan menindaklanjuti temuan-temuan ketika melaksanakan supervisi akademiknya. Program supervisi akademik yang harus disusun oleh seorang kepala sekolah merupakan pedoman atau acuan dalam melaksanakan supervisi akademik. Selain itu, program supervisi akademik juga dapat mengembangkan kemampuan guru dalam mengelola pembelajaran secara efektif. Dari hasil pelaksanaan supervisi akademik, kepala sekolah juga harus mampu merefleksi kinerjanya dan melaksanakan tindak lanjut sebagai umpan balik yang sangat berguna untuk peningkatan kualitas baik bagi siswa, guru, maupun dirinya yang pada akhirnya dapat meningkatkan kualitas pendidikan di sekolahnya.

Berdasarkan hasil refleksi diri yang telah dilakukan oleh peneliti sebagai kepala sekolah, selama ini kepala sekolah melaksanakan tugas supervisi akademiknya dengan menerapkan pendekatan supervisi langsung secara individual, dengan cara mendatangi guru yang sedang bertugas, mengamati kinerjanya dan melakukan penilaian. Pendekatan supervisi individual ini tidak terlalu efektif untuk meningkatkan kompetensi guru dalam melaksanakan tugasnya khususnya yang berkaitan dengan kompetensi profesionalnya. Hasil kajian empirik yang peneliti lakukan terhadap guru-guru di SD Negeri 2 Plandi Kecamatan Wonosari Kabupaten Malang menunjukkan bahwa kompetensi profesional guru masih rendah terutama pada kompetensi guru dalam mengembangkan materi pembelajaran yang diampu secara kreatif. Rata-rata kemampuan guru dalam mengembangkan materi pembelajaran yang diampunya berdasarkan penilaian kinerja guru terhadap 6 orang guru di SD Negeri 2 Plandi Kecamatan Wonosari Kabupaten Malang, menunjukkan bahwa kompetensi guru dalam mengembangkan materi pembelajaran yang diampu masih pada kategori sedang yaitu indeks rata-rata 2,09 atau 52,27. Hasil refleksi terhadap temuan tersebut menunjukkan bahwa faktor yang menyebabkan masih rendahnya kompetensi guru tersebut 
diduga disebabkan oleh faktor internal dan eksternal. Faktor internal yang diduga mempengaruhi rendahya kompetensi profesional guru antara lain: (1) Guru belum memahami teknik pengembangan materi pembelajaran; (2) Guru tidak melakukan analisis materi pembelajaran sebelum mengembangkan bahan ajar atau materi pembelajaran; dan (3) Kurangnya motivasi diri guru untuk melakukan kinerja profesionalnya dengan baik.

Faktor eksternal yang diduga mengakibatkan rendahnya kompetensi profesional guru adalah pelaksanaan supervisi oleh kepala sekolah yang lebih bersifat menilai. Idealnya, supervisi dilaksanakan secara kolegial, tidak menggurui, bersifat kemitraan dan pendampingan, serta dilakukan melalui diskusi dan curah pendapat secara terbuka dan fleksibel untuk membantu guru merefleksi kinerjanya dalam melaksanakan tugas profesionalnya. Salah satu pendekatan yang mengedepankan kemitraan atau rekan kerja antara kepala sekolah sebagai supervisor akademik dan guru sebagai orang yang disupervisi, lebih bersifat mendampingi melalui diskusi dan curah pendapat secara terbuka dan fleksibel serta memiliki tujuan yang jelas untuk membantu guru berkembang menjadi tenaga-tenaga profesional melalui kegiatan-kegiatan reflektif adalah pendekatan supervisi kolaboratif.

Mempertimbangkan kondisi tersebut, maka salah satu upaya yang dapat dilakukan oleh peneliti untuk mengatasi masalah rendahnya kompetensi profesional guru dalam melaksanakan tugas profesionalnya, maka diterapkan tindakan berupa pendekatan supervisi yang belum pernah dilakukan sebelumnya yaitu pendekatan supervisi kolaboratif.

Berdasarkan latar belakang tersebut di atas, maka tujuan Penelitian Tindakan Sekolah (PTS) ini adalah: (1) untuk mendeskripsikan perkembangan proses supervisi kolaboratif guna meningkatkan kompetensi profesional guru di SD Negeri 2 Plandi Kecamatan Wonosari Kabupaten Malang; dan (2) untuk mengidentifikasi peningkatan kompetensi profesional guru di SD Negeri 2 Plandi Kecamatan Wonosari Kabupaten Malang setelah diterapkan pendekatan supervisi kolaboratif.

\section{METODE PENELITIAN}

\section{A. Metode dan Model Penelitian}

Metode penelitian yang digunakan pada penelitian ini adalah metode Penelitian Tindakan Sekolah (PTS) dengan model Kemmis dan Mc. Taggart yang merupakan model pengembangan dari model Kurt Lewin. Dikatakan demikian, karena di dalam suatu siklus terdiri atas empat komponen, keempat komponen tersebut, meliputi: perencanaan, (2) aksi/tindakan, observasi, dan (4) refleksi. Setelah suatu siklus selesai diimplementasikan, khususnya sesudah adanya refleksi, kemudian diikuti dengan adanya perencanaan ulang yang dilaksanakan dalam bentuk siklus tersendiri

\section{B. Lokasi Penelitian}

Penelitian ini dilakukan di SD Negeri 2 Plandi Kecamatan Wonosari Kabupaten Malang yang memiliki karakteristik bahwa di sekolah ini kepala sekolah selalu melakukan supervisi akademik secara individual, tidak secara 
kolaboratif padahal karakteristik guru di sekolah ini adalah dapat bekerja secara kolaboratif dan memiliki motivasi untuk selalu merefleksi kinerjanya dan berbagi pengalaman dengan rekan sejawatnya.

\section{Subyek Penelitian}

Dalam penelitian ini yang menjadi subyek penelitian adalah 6 guru di SD Negeri 2 Plandi Kecamatan Wonosari Kabupaten Malang yang memiliki karakteristik bahwa kompetensi profesionalnya rendah khususnya dalam mengembangkan materi pembelajaran. Namun, guru di sekolah ini dapat bekerja secara kolaboratif dan memiliki motivasi untuk selalu merefleksi kinerjanya serta berbagi pengalaman dengan rekan sejawatnya.

\section{Waktu Penelitian}

Jadwal pelaksanaan penelitian tindakan sekolah dengan menerapkan pendekatan supervisi kolaboratif untuk meningkatkan kompetensi profesional guru telah dikoordinasikan dan disepakati bersama 6 guru yaitu pada bulan September s.d. Desember 2018 (4 bulan)

\section{E. Prosedur Penelitian}

\section{Siklus I}

1. Perencanaan

a. Merencanakan proses supervisi kolaboratif sesuai dengan prinsipprinsip pendekatan supervisi kolaboratif.

b. Menyusun instrumen penelitian berupa lembar observasi proses supervisi kolaboratif, lember observasi kinerja profesional guru dalam mengembangkan materi pembelajaran, panduan wawancara dan catatan lapangan.

c. Melakukan analisis kebutuhan guru

d. Sesuai jadwal, peneliti memberikan materi tentang teknis pengembangan materi pembelajaran dan bahan ajar

e. Menyepakati jadwal kegiatan pada pertemuan berikutnya

2. Pelaksanaan Tindakan

a. Melaksanakan diskusi dan curah pendapat antara kepala sekolah dengan 6 guru tentang masalahmasalah krusial pada saat mengembangkan materi pembelajaran dan bahan ajar.

b. Melaksanakan tindakan berupa supervisi kolaboratif antara kepala sekolah dan guru dengan melaksanakan kelima prinsip pendekatan supervisi kolaboratif yaitu prinsip kolaboratif, kolegial, kemitraan, terbuka dan fleksibel.

c. Melaksanakan refleksi bersama antara kepala sekolah dan 6 guru tentang pelaksanaan kinerja profesionalnya pada kelompok kerja guru difasilitasi oleh kepala sekolah.

\section{Observasi}

Observasi dilaksanakan oleh kepala sekolah terhadap proses supervisi kolaboratif yang sedang dilaksanakan dan kinerja profesional guru dalam mengembangkan materi pembelajaran dan bahan ajar dan mencatat semua temuannya pada instrumen yang telah disediakan. Berikut adalah fokus-fokus dari kegiatan observasi: 
a. Proses supervisi kolaboratif yang terdiri dari pelaksanaan kelima prinsip pendekatan supervisi kolaboratif yaitu prinsip kolaboratif, kolegial, kemitraan, terbuka dan fleksibel

b. Kompetensi profesional guru dalam mengembangkan materi pembelajaran dan bahan ajar

4. Tahap Analisis dan Refleksi

Pada tahap ini, semua data yang terkumpul dianalisis. Hasil analisis tersebut digunakan sebagai bahan refleksi untuk merumuskan rekomendasi-rekomendasi pada Siklus II berdasarkan temuan-temuan pada Siklus I terkait proses supervisi kolaboratif dan kompetensi profesional guru. Pada kegiatan refleksi, temuan-temuan pada Siklus I diklarifikasi dan dirumuskan tindak lanjutnya untuk diterapkan pada Siklus II.

\section{Siklus II}

1. Perencanaan

a. Memperbaiki perencanaan proses supervisi kolaboratif berdasarkan rekomendasi-rekomendasi pada Siklus I

b. Melakukan analisis kebutuhan guru

2. Pelaksanaan Tindakan

a. Melaksanakan diskusi dan curah pendapat antara kepala sekolah dengan 6 guru tentang masalahmasalah krusial pada saat melaksanakan kinerja profesionalnya dalam mengembangkan materi pembelajaran dan bahan ajar b. Melaksanakan tindakan berupa supervisi kolaboratif antara kepala sekolah dan guru dengan melaksanakan kelima prinsip pendekatan supervisi kolaboratif yaitu prinsip kolaboratif, kolegial, kemitraan, terbuka dan fleksibel

c. Melaksanakan refleksi bersama antara kepala sekolah dan 6 guru tentang pelaksanaan kinerja profesionalnya difasilitasi oleh kepala sekolah.

3. Observasi

Observasi dilaksanakan oleh kepala sekolah terhadap proses supervisi kolaboratif yang sedang dilaksanakan dan kinerja profesional guru dalam mengembangkan materi pembelajaran dan bahan ajar dan mencatat semua temuannya pada instrumen yang telah disediakan. Berikut adalah fokus-fokus dari kegiatan observasi:

a. Proses supervisi kolaboratif yang terdiri dari pelaksanaan kelima prinsip pendekatan supervisi kolaboratif yaitu prinsip kolaboratif, kolegial, kemitraan, terbuka dan fleksibel

b. Kompetensi profesional guru dalam mengembangkan materi pembelajaran dan bahan ajar

4. Tahap Analisis dan Refleksi

Pada tahap ini, semua data yang terkumpul dianalisis. Hasil analisis tersebut digunakan sebagai bahan refleksi untuk merumuskan rekomendasi-rekomendasi

berdasarkan temuan-temuan pada Siklus II terkait proses supervisi kolaboratif dan kompetensi profesional guru. Pada kegiatan 
refleksi, temuan-temuan pada Siklus

II diklarifikasi dan dirumuskan tindak lanjutnya.

\section{HASIL DAN PEMBAHASAN}

Berikut merupakan perkembangan temuan selama proses supervisi dengan menerapkan pendekatan supervisi kolaboratif dari siklus I ke siklus II.

Tabel 1

Perkembangan Temuan selama Proses Supervisi dengan Menerapkan Pendekatan Supervisi Kolaboratif

\begin{tabular}{|c|c|c|}
\hline Tahapan & Siklus I & Siklus II \\
\hline $\begin{array}{l}\text { Pra-Supervisi } \\
\text { Kolaboratif }\end{array}$ & $\begin{array}{l}\text { Seluruh guru tidak membawa daftar } \\
\text { masalah terkait kinerja } \\
\text { profesionalnya, curah pendapat dan } \\
\text { diskusi tidak berjalan dengan baik, } \\
\text { hanya satu guru yaitu G05 yang aktif } \\
\text { mencurahkan pendapatnya }\end{array}$ & $\begin{array}{l}\text { Curah pendapat dan diskusi berjalan dengan } \\
\text { baik, seluruh guru aktif berdiskusi dan } \\
\text { mencurahkan pendapatnya }\end{array}$ \\
\hline $\begin{array}{l}\text { Pelaksanaan } \\
\text { Supervisi } \\
\text { Kolaboratif }\end{array}$ & $\begin{array}{l}\text { Guru G03 dan G06 tidak menyiapkan } \\
\text { kelengkapan berupa hasil analisis } \\
\text { materi pembelajaran sehingga } \\
\text { mengganggu proses supervisi } \\
\text { kolaboratif }\end{array}$ & $\begin{array}{l}\text { Pelaksanaan supervisi kolaboratif berjalan } \\
\text { dengan efektif, guru mampu menerapkan } \\
\text { solusi-solusi dari masalah yang } \\
\text { teridentifikasi sebelumnya sebagai hasil } \\
\text { curah pendapat dan diskusi dengan guru } \\
\text { lain dan kepala sekolah pada tahap pra- } \\
\text { supervisi kolaboratif. }\end{array}$ \\
\hline $\begin{array}{l}\text { Pasca- } \\
\text { Supervisi } \\
\text { Kolaboratif }\end{array}$ & $\begin{array}{l}\text { Seluruh guru terlibat dalam proses } \\
\text { refleksi pelaksanaan supervisi } \\
\text { kolaboratif dengan menyampaikan } \\
\text { temuan dan pemecahannya }\end{array}$ & Seluruh guru terlibat dalam proses refleksi \\
\hline
\end{tabular}

Berdasarkan hasil pengisian lembar observasi kinerja profesional guru dalam mengembangkan materi pembelajaran dan bahan ajar, dapat diketahui bahwa skor rata-rata kompetensi profesional guru dalam mengembangkan materi pembelajaran dan bahan ajar mengalami peningkatan sebagaimana tampak pada tabel berikut.

\section{Tabel 2}

Peningkatan Kompetensi Profesional Guru

\begin{tabular}{cccc}
\hline Kompetensi & $\begin{array}{c}\text { Pra- } \\
\text { siklus }\end{array}$ & $\begin{array}{c}\text { Siklus } \\
\text { I }\end{array}$ & $\begin{array}{c}\text { Siklus } \\
\text { II }\end{array}$ \\
\hline Rata-rata & 52,27 & 70,45 & 88,64 \\
Kriteria & Kurang & Cukup & Baik \\
\hline
\end{tabular}




\section{SIMPULAN DAN SARAN}

\section{A. Simpulan}

\begin{tabular}{lrr}
\multicolumn{2}{c}{ Berdasarkan } & pembahasan \\
dalam & penelitian & mengenai \\
penerapan & pendekatan & supervisi \\
kolaboratif & untuk meningkatkan \\
kompetensi profesional guru di SD
\end{tabular} Negeri 2 Plandi Kecamatan Wonosari Kabupaten Malang dapat ditarik beberapa simpulan sebagai berikut:

1. Proses supervisi dengan menerapkan pendekatan supervisi kolaboratif secara spesifik terdiri dari tahap pra-supervisi kolaboratif, supervisi kolaboratif dan pasca-supervisi kolaboratif. Proses supervisi dengan menerapkan pendekatan supervisi kolaboratif mengalami perkembangan dari Siklus I ke Siklus II. Pada tahap prasupervisi kolaboratif Siklus I, curah pendapat tidak berjalan dengan efektif karena kepala sekolah tidak melakukan koordinasi dengan semua guru dan tidak menjelaskan teknis supervisi kolaboratif yang akan dilaksanakan diantaranya mengindentifikasi masalahmasalah krusial ketika guru melaksanakan kinerja profesionalnya, mencatat dan membawanya pada saat curah pendapat dan diskusi bersama kepala sekolah dan guru lainnya. Kemudian pada Siklus II, kepala sekolah melakukan koordinasi dengan semua guru dan menjelaskan teknis supervisi kolaboratif yang akan dilaksanakan serta menguatkan dan menegaskan kepada guru untuk menyiapkan kelengkapan terkait kinerja profesionalnya sehingga curah pendapat dan diskusi berjalan dengan tertib dan efektif. Pada tahap supervisi kolaboratif Siklus I, proses supervisi kolaboratif terhambat karena guru tidak membawa kelengkapan terkait kinerja profesionalnya, sedangkan pada Siklus II mereka membawa semua kelengkapan sehingga pelaksanaan supervisi kolaboratif berjalan dengan tertib. Pada tahap pasca-supervisi kolaboratif, kepala sekolah tidak koordinatif dengan semua guru dan tidak berhasil memotivasi guru untuk saling belajar. Sedangkan pada Siklus II, kepala sekolah mulai koordinatif dengan semua dan berhasil memotivasi guru untuk saling belajar.

2. Peningkatan kompetensi profesional guru di SD Negeri 2 Plandi Kecamatan Wonosari Kabupaten Malang dari prasiklus ke Siklus I sebesar 18,18 poin. Rata-rata kompetensi profesional guru pada pra-siklus sebesar 52,27 dengan kriteria kurang dan pada Siklus I sebesar 70,45 dengan kriteria cukup. Kompetensi profesional guru juga mengalami peningkatan dari Siklus I ke Siklus II sebesar 
18,19 poin. Rata-rata kompetensi profesional guru pada Siklus II sebesar 88,64 dengan kriteria baik. Jadi, dapat disimpulkan bahwa kompetensi profesional guru di SD Negeri 2 Plandi Kecamatan Wonosari Kabupaten Malang dapat ditingkatkan melalui penerapan pendekatan supervisi kolaboratif

\section{B. Saran}

Sebagai implikasi dari hasil penelitian, berikut ini dikemukakan rekomendasi yang diharapkan dapat memberikan sumbangan pemikiran dalam upaya meningkatkan kualitas supervisi oleh kepala sekolah, khususnya dalam menerapkan dan mengembangkan pendekatan supervisi kolaboratif.

1. Pada tahap pra-supervisi kolaboratif, kepala sekolah harus terlebih dahulu melakukan koordinasi dengan semua guru dan menjelaskan teknis supervisi kolaboratif yang akan dilaksanakan diantaranya mengindentifikasi masalahmasalah krusial ketika guru melaksanakan kinerja profesionalnya, mencatat dan membawanya pada saat curah pendapat dan diskusi bersama kepala sekolah dan guru lainnya.

2. Pada tahap supervisi kolaboratif, kepala sekolah harus menerapkan prinsip-prinsip pendekatan supervisi kolaboratif yaitu prinsip kolaboratif, kolegial, kemitraan, terbuka dan fleksibel.

3. Pada tahap pasca-supervisi kolaboratif, kepala sekolah harus koordinatif dengan guru dan memotivasi guru untuk saling belajar.

\section{DAFTAR PUSTAKA}

Alfonso, RJ., Firth, G.R., dan Neville,

R.F.1981. Instructional Supervision, A Behavior System, Boston: Allyn and Bacon, Inc.

Ali Mohamad, 1987, Pengantar Statistik, Bandung.

Danim, Sudarwan. 2006. Visi Baru Manajemen Sekolah. Jakarta: Bumi Aksara.

Departemen Pendidikan dan Kebudayaan RI. 1982. Alat Penilaian Kemampuan Guru: Buku I. Jakarta: Proyek Pengembangan Pendidikan Guru.

Direktorat Tenaga Pendidik - Dirjen PMPTK - Depdiknas RI, 2007, Supervisi Akademik dalam Peningkatan Profesionalisme Guru, Jakarta.

Direktorat Tenaga Pendidik - Dirjen PMPTK - Depdiknas RI, 2008, Metode dan Teknik Supervisi, Jakarta.

Direktorat Pembinaan Pendidik dan Tenaga Kependidikan Pendidikan Dasar Direktorat Jenderal Pendidikan Dasar 
Kementerian Pendidikan dan

Kebudayaan, 2014, Supervisi

Pembelajaran - Bahan Materi

Bimbingan Teknis Penguatan

Kepala Sekolah, Jakarta.

Glickman, C.D 1995. Supervision of

Instruction. Boston: Allyn And

Bacon Inc.

Gwynn, J.M. 1961. Theory and

Practice of Supervision. New

York: Dodd, Mead \&

Company.

McPherson, R.B., Crowson, R.L., \&

Pitner, N.J. 1986. Managing

Uncertainty: Administrative

Theory and Practice in

Education. Columbus, Ohio:

Charles E. Merrill Pub. Co.

Nolan, J.F. 2011. Teacher

Supervision and Evaluation.

Wiley: United State of America.

Oliva, Peter F. 1984. Supervision

For Today's School. New

York: Longman.

Peraturan Menteri Pendidikan

Nasional No. 13 tahun 2007

tentang Standar Kompetensi

Kepala Sekolah/Madrasah,

Jakarta.

Peraturan Menteri Pendidikan

Nasional No. 41 tahun 2007

tentang Standar Proses

Jakarta.

Pidarta, Made. 1992. Pemikiran

Tentang Supervisi Pendidikan.

Jakarta: Bumi Aksara.
Purwadarminta, 2003, Kamus Umum

Bahasa Indonesia, Balai

Pustaka Jakata.

Purwanto,

Ngalim.2003.

Administrasi dan Supervisi

Pendidikan. Bandung:

Rosdakarya

Pusat Pengembangan Tenaga

Kependidikan - Badan

PSDMP \& $\mathrm{K}$ dan PMP

Kementerian Pendidikan dan

Kebudayaan, 2012, Supervisi

Akademik - Bahan

Pembelajaran Utama -

Pengembangan Keprofesian

Berkelanjutan Tingkat I

Kepala Sekolah

Dasar/Madrasah Ibtidaiyah.

Jakarta

Sagala dalam Zakir Hubolo (Jumat, 18 Maret 2011: 18:III)

Sergiovanni, T.J. 1982. Editor.

Supervision of Teaching.

Alexandria: Association for

Supervision and Curriculum

Development.

Sergiovanni, T.J. 1987. The

Principalship, A Reflective

Practice Perspective. Boston:

Allyn and Bacon.

Sergiovanni, T.J. dan R.J. Starrat.

1979. Supervision: Human

Perspective. New York:

McGraw-Hill Book

Company.

Setya AP, 12 Februari 2012,

Supervisi Pendidikan, FIP UNY 